Int. J. Dev. Biol. 59: 5-9 (2015)

doi: $10.1387 / \mathrm{ijdb} .150167 \mathrm{mp}$

\title{
Dying to survive - apoptosis, necroptosis, autophagy as supreme experiments of nature
}

\author{
MAURO PIACENTINI* and GUIDO KROEMER \\ Department of Biology, University of Rome 'Tor Vergata', Rome, Italy
}

\begin{abstract}
Guido Kroemer has made fundamental contributions to medical research through his pioneering work in the fields of cell death and cancer research. He is best known for the discovery that the permeabilization of mitochondrial membranes constitutes a decisive step in programmed cell death. Kroemer has explored the fine mechanisms of mitochondrial cell death control, the molecular pathways that explain the inhibition of cell death in cancer cells, upstream of or at the level of mitochondria, and the mechanisms that make cancer cell death immunogenic. Moreover, he discovered the AIF protein and clarified its biological role in apoptosis. His important contributions have been recognized with numerous awards. Kroemer currently serves on more than forty Editorial Boards and is a member of the European Molecular Biology Organization (EMBO), German Academy of Sciences, Austrian Academy of Sciences, European Academy of Sciences (EAS), European Academy of Sciences and Arts (EASA), and European Academy of Cancer Sciences (EACS). He is the President of the European Cell Death Organization (ECDO) and the Founding Director of the European Research Institute for Integrated Cellular Pathology (ERI-ICP). Kroemer is the most cited scientist worldwide in the field of cell death as well as in the area of mitochondrial research.
\end{abstract}

KEY WORDS: apoptosis, autophagy, necrosis, tumor immunology

I met Prof. Kroemer in his laboratory at the Centre de Recherché des Cordoliers, in Paris and started by asking him the first obvious question that came to my mind:

\section{When and why did you decide to study cell death/autophagy?}

I started to work on cell death back in 1991 because I was intrigued by one particular mechanism of immune tolerance, the mechanism that usually avoids autoimmune disease, that consists in "peripheral T cell deletion". In specific circumstances, T lymphocytes bearing specific receptors die when they are confronted with self-antigen and so-called "super-antigens". Moreover, as we discovered, Tlymphocytes die in the presence of supraphysiological concentrations of glucocorticoid. However, even in conditions in which $10 \%$ of certain $\mathrm{T}$ cell populations died per hour, we failed to observe any oligonucleosomal DNA fragmentation (which back then was considered as THE biochemical hallmark of apoptosis) in purified T cells. These apoptosis-associated changes that we were searching for ex vivo, among splenocytes or thymocytes from mice that had been treated in vivo, only occurred upon in vitro culture of dissociated lymphoid organs, suggesting that the cells were programmed to disappear - presumably by phagocytosis - before they manifested DNA fragmentation and that the latter constituted a sort of in vitro artefact that only manifested when phagocytic removal of pre-apoptotic cells was disrupted. As a result, we tried to identify biochemical changes that would define the population of T cells that is doomed to die, and we found that the loss of the mitochondrial transmembrane potential, as identified by labelling with specific fluorophores, was able to define the pre-apoptotic population. This was the very beginning of our work on the cell biology of programmed cell death (PCD). This serendipitous start coincided with my move from Madrid, where I headed a lab at the National Center of Biotechnology, to Paris, where I joined INSERM, the National Medical Research Institute, at the end of 1993. Although my initial project in France was to continue working on $\mathrm{T}$ cell tolerance and superantigens, I was confronted with two major problems. First, funding in basic immunology was scarce. Second, worse, the director of the local animal facility refused to collaborate with me, meaning that any genetic work on mouse models of immune tolerance became impossible. So, I took the strategic decision to change my carrier from immunology to cell biology and to focus

Abbreviations used in this paper: PCD, programmed cell death.

\footnotetext{
*Address correspondence to: Mauro Piacentini. National Institute for Infectious Diseases I.R.C.C.S. 'Lazzaro Spallanzani' Rome, 00149, Italy and Department of Biology, University of Rome ‘Tor Vergata', Rome, 00133, Italy e-mail: mauro.piacentini@ uniroma2.it (Kroemer e-mail: Kroemer@orange.fr)
} 
on cell death research with the intuition that this field would gain major importance in the areas of cancer and AIDS research. A posteriori, I think that this was a wise decision. However, I have not completely abandoned my interest in immunology, and nowadays much of my scientific activity in biomedicine deals with the immune recognition of antigens from dying cells.

As to autophagy, I became interested in the lysosomal pathway of self-destruction back in 2002 or so. We used lysotropic antibiotics such as ciprofloxacin to induce lysosomal membrane permeabilization (LMP) and to discover that this phenomenon induced later mitochondrial membrane permeabilization (MMP), a finding that we published in 2003, in the Journal of Experimental Medicine (JEM). On the cover page of that volume of JEM, we were invited to show the electron microscopic picture of ciprofloxacin-treated cells. These cells actually exhibited a vacuolated phenotype with occasional autophagosomes. Like most of my colleagues, I naively assumed that autophagy would be a cell death modality distinct from apoptosis. However, when we knocked down essential autophagy-relevant genes, we found that this manipulation actually sensitized the cells to the induction of apoptosis by nutrient depletion. So, we launched the hypothesis, first published in 2005, that autophagy would be, in principle, a cytoprotective mechanism, allowing cells to catabolize portions of the cytoplasm for meeting their bioenergetics demand and to recycle (and hence to renew) damaged cellular structures. Since then, we are studying the mechanisms through which different kinds of stress can stimulate autophagy and how autophagy can avoid unwarranted cell death.

\section{Why is the field of cell death/autophagy so important to you?}

Beyond proliferation and differentiation, there are two major phenomena in cell biology that are spectacular enough to be visible by conventional light microscopy, namely cell death and macroautophagy (to which I refer to as 'autophagy'). It is fascinating and exciting to observe how cells disintegrate, be it by apoptosis or by necrosis, or how they attempt to avoid death by autophagy. The opposing forces of the universe, death and life, can be contemplated in a simple cell culture. Beyond this aesthetic and philosophical consideration, it is obvious that the advent of cell death or its avoidance constitute the very heart of pathophysiology. Since, I am an MD (and I am even nowadays a 'hospital practicioner' in the area of cell biology), I have the idea that diseases constitute the supreme experiments of nature, meaning that pathologies can teach us lessons on how biological mechanism usually (should) work and how the can go awry. To inverse the logics, if we we study problems that are biologically relevant, we will understand the underlying principles of human disease. And there is no major disease that is not linked to unwarranted cell death or, on the contrary, to the undue persistence of cells that should have been eliminated.

\section{Who were the people that had a major influence on your career or your science?}

Beyond a few mentors that gave me positive (and sometimes negative) examples about how to live a scientific life, the people that had a major influence on my career can be divided into two (non fully separable) categories: alumni and colleagues. I had the chance and the pleasure to work with many absolutely amaz-

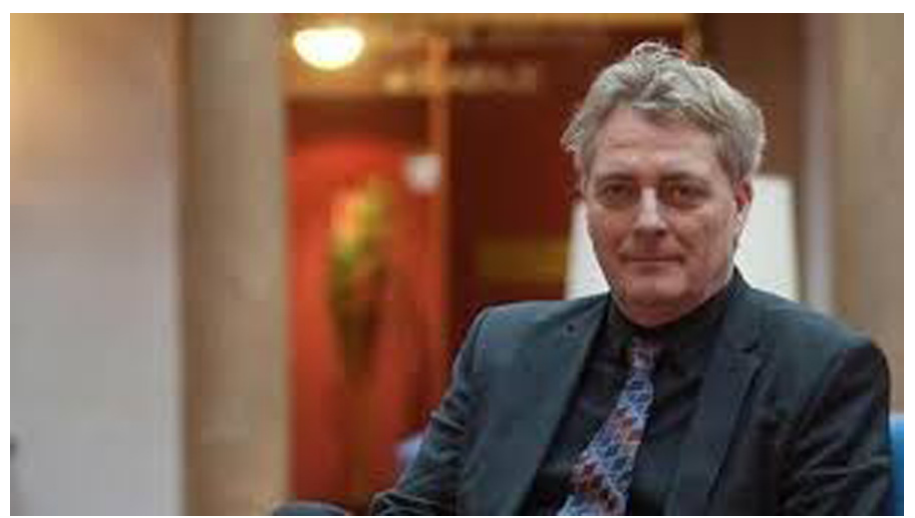

Fig. 1. Guido Kroemer in his new office at the Faculty of Medicine of the University of Paris Descartes in Paris in 2014.

ing PhD students and post-docs, who have done the work that made our laboratory one of the leading places in the world, in the area of cell (death) biology. Fortunately, some of my alumni are still collaborating with me, creating an important network of productive interactions. Moreover, I have met a few exceptional friends during my career with whom I have been collaborating extensively. For example, I coincided during my MD/PhD in Innsbruck, Austria, with Josef Penninger, with whom I have been working since then, publishing more than 30 joint papers. Ten years ago I started publishing with my wife, Laurence Zitvogel, and we have now generated more than 150 joint publications. I have also been extensively collaborating with other friends with whom we practice what one might call an 'open laboratory', i.e. continuous informal cooperation among laboratory staff that does not require any top-down coordination. Prominent examples for this kind of cooperation are the labs of Mauro Piacentini (37 joint papers since 2001), Frank Madeo (70 joint papers since 2004) and Carlos López-Otín (9 joint papers since 2011). I am indebted to many colleagues who contributed help, reagents, ideas and discussions, but I would especially like to acknowledge the enlightenment by and friendship of Sebastian Amigorena, Klas Blomgren, Catherine Brenner, Francesco Cecconi, Klaus-Michael Debatin, Hugues de Thé, Pierre Fenaux, Jean Feunteun, Hervé Fridman, Carmen Garrido, Victor Goldmacher, Pierre Golstein, Marie-Lise Gougeon, Douglas R. Green, Michael Hengartner, Alain Israel, Marja Jäättelä, Adi Kimchi, Peter Krammer, Sergio Lavandero, Beth Levine, Luigi Maiuri, Seamus J. Martin, Gerry Melino, Sten Orrenius, John C. Reed, Rosario Rizzuto, Bernard Roques, Gérard Pierron, Catherine Sautés-Fridman, Jean-Charles Soria, Peter Vandenabeele, Boris Zhivotovsky and Hans Zischka, just to mention a few. Special thanks to Maria Castedo, Lorenzo Galluzzi, Chiara Maiuri, Laura Senovilla and Naoufal Zamzami, as well as to the past and current members of our laboratory, for contributing to the success of the team.

\section{Where do you think the field is heading? What are its key questions to be addressed?}

Where does the field stand? In my subjective appreciation, I am oscillating between two extremes. On the one hand, one might say that the 'central machinery' of apoptosis, necroptosis and autophagy has been deciphered, meaning that the key questions have been solved and that the field of cell death research 


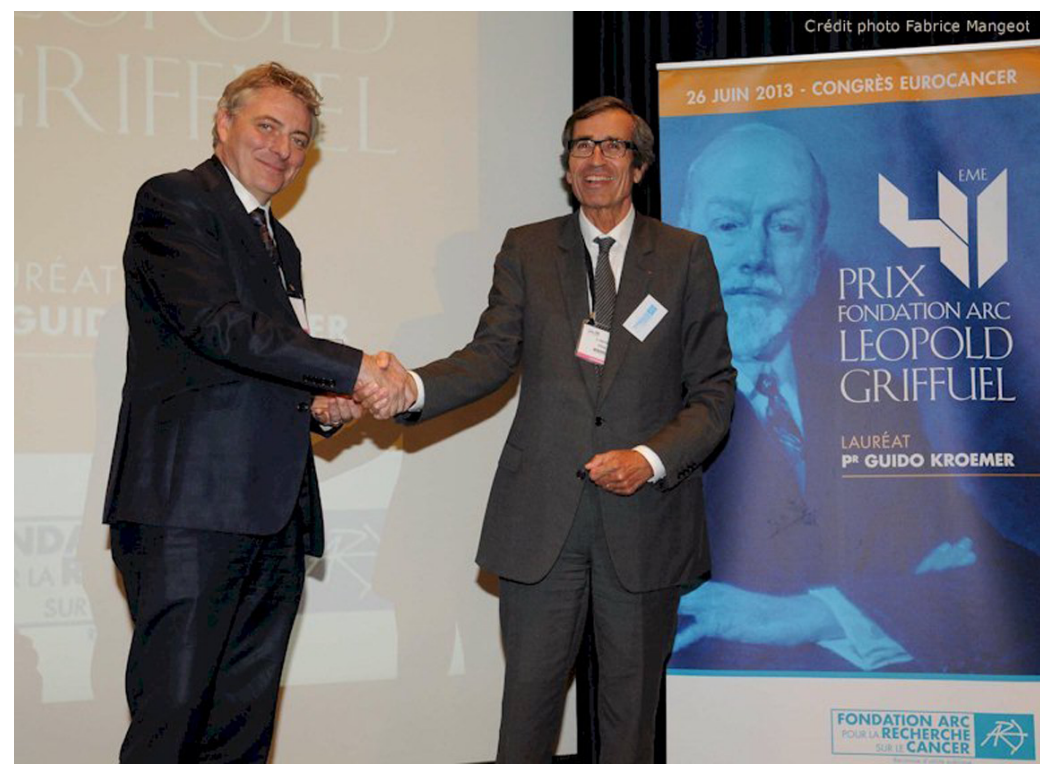

Fig. 2. Guido Kroemer receiving from Jacques Raynaud the very prestigious award from the "Fondation ARC Léopold Griffuel" for his important contributions to cancer research (2013).

should now fragment into smaller entities with more specific research interests and/or re-establish contacts with other areas of biology and pathophysiology. On the other hand, one might say that none of the key questions has been solved. We still do not understand in detail why and how cells die during human embryonic development. And we have certainly not succeeded in interrupting lethal signalling to save cells from programmed death. So far, there are no magical pills that would avoid cardiomyocytes from dying upon infarction or that would rescue the function of degenerating neurons. So everything that is important
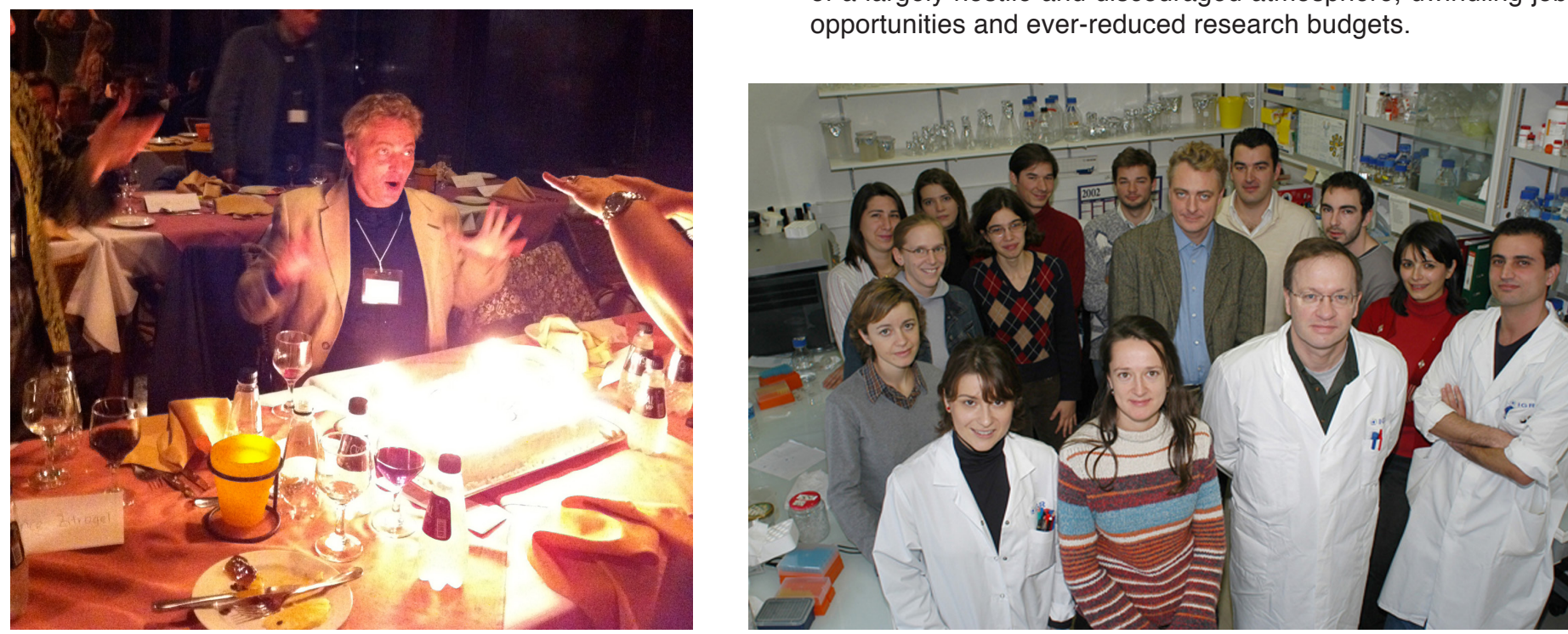

Fig. 3 (left). Guido Kroemer celebrating his 50th birthday during the International Cell Death Society Conference held at the Cheiro de Mato Resort of Maripora close to São Paulo, Brazil, on June 2011. During the Conference Guido Kroemer received the "Carreer Award" for his important contributions to the cell death field.

Fig. 4 (right). Guido Kroemer and his team at Institut Gustave Roussy in Villejuif near Paris in 2007. still remains to be discovered. We do not know yet why we age and how we can halt or reverse the process. We have no precise idea how certain pathologies accelerate general or organ-specific features of aging. We have not developed much 'precision medicines' that would specifically abort malignant cells yet leave intact their normal counterparts. And so forth... I think it would be a major illusion to believe that the field of cell death research has come close to the frontiers of possible knowledge. However, it is possible that new ways to apprehend science involving more systematic approaches (systems biology, 'omics' technology, as well as trans-disciplinary methods linking for instance biophysics to biochemistry etc.) will shape future research orientations in the field.

\section{What do you think are the most important achievements of your scientific career?}

First of all, I am still surprised by the fact that the French system has allowed me to get that far. As an immigrant, I have been well treated and rarely if ever discriminated against. Definitively, the Parisian melting pot has given me an opportunity! So, my gratitude towards my adoptive country and my French colleagues is absolute. Without their magnanimity and support, I would not have been able to achieve anything. Paradoxically, I think that my most important achievement is not directly linked to the scientific production of the team that I lead, more than 500 papers over the last 10 years. No, the most important achievement has been the possibility to create a fantastic group of enthusiastic young collaborators with whom it is a pleasure to interact and work. In a way, we have been able to create a (fragile) bubble of cheerful striving for scientific perfection, mostly in a highly cooperative, non-competitive spirit. I think it is immensely important to create small islets of happiness in our proximity, within the distance that we can influence, in spite of a largely hostile and discouraged atmosphere, dwindling job opportunities and ever-reduced research budgets. 


\section{What key findings which have contributed to the de- velopment of the cell death/autophagy field stand out in your mind?}

Well, I think that there are three major findings that did have a major impact on the general appreciation of cell (death) biology. First, our team pioneered the idea that mitochondrial membrane permeabilization controls cell death, a hypothesis that we published with some convincing experimental support back in 1995, meeting strong opposition in the field. We have continued to work on the mitochondrial cell death hypothesis ever since, publishing some 300 papers in this research area to reveal many details on mitochondrial membrane permeabilization, its upstream regulation, execution, and downstream consequences. As you know, at the end the idea that metabolic alterations affecting mitochondria delimit the fine line between life and death has overcome and completely revolutionized the field of cell death research. Of course, caspases can precipitate the morphological changes accompanying apoptosis, but we all know in the meantime that it is close-to-impossible to rescue cells from their lethal fate by inhibiting caspases. So, if we want to prevent cell death, we must interfere with the initiating, pre-mitochondrial and the executing mitochondrial events, not with the post-mortem phase that comes into action after mitochondria have lost their function.

Second, our team has launched the hypothesis that autophagy is generally a cytoprotective process and that its induction at the whole-organism level may promote an extension of health span and lifespan. In its extreme formulation, this hypothesis postulates that any genetic, pharmacological or nutritional manipulation that succeeds in prolonging longevity does so by inducing an increase in autophagic flux. To the best of my knowledge, this postulate has not been invalidated thus far. It is our hope that specific induction of autophagy by nutritional or behavioural cues may constitute a strategy to enhance human wellbeing coupled to healthy aging.

Third, our collective efforts have resolved the mode of action of successful anticancer chemotherapies. We observed that several widely used chemotherapeutic agents were much more effective in reducing tumor growth when they can operate in the context of an intact immune system. We subsequently developed the concept of 'immunogenic cell death', a specific modality of cellular demise

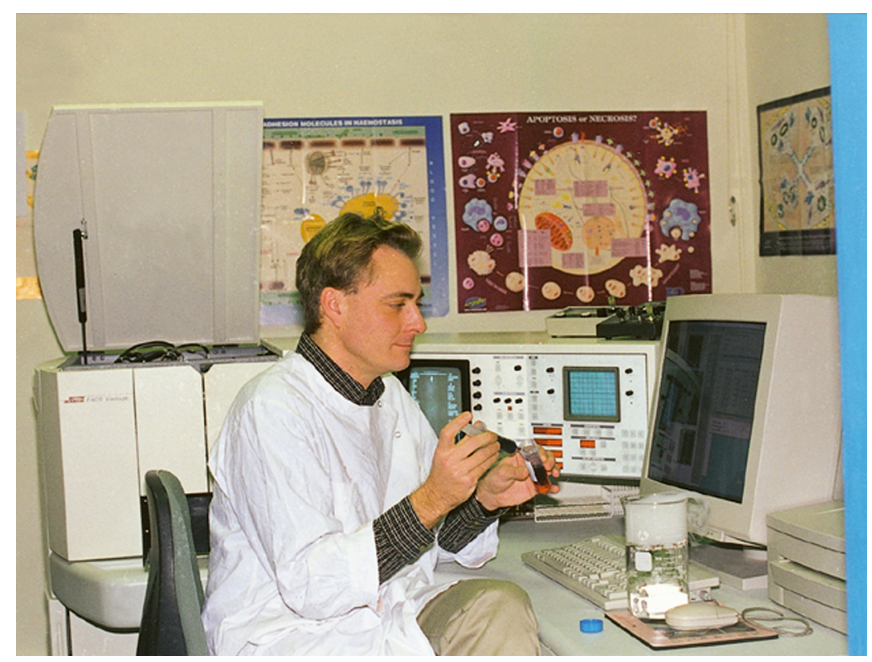

Fig. 5. Guido Kroemer working in his laboratory at the Institut Gustave Roussy in Villejuif near Paris in 2001. in which premortem stress responses affecting the cancer cell are communicated to the extracellular space in a way that the immune system is alerted, causing a specific T lymphocyte response against tumor-associated antigens. This concept, which has been validated at the clinical level, has changed and will change the design of future anticancer chemotherapies, as well as their combination with immunotherapies.

\section{You have trained many people in your lab. What has been your philosophy regarding the formation of scientists?}

Close to forty-five of my former alumni have achieved independent positions in academia. As my career advances, the progress of my alumni becomes more and more important for my selfevaluation. Will I have been able to launch some stellar carriers that hopefully will be much better than mine? Perhaps because I do not have a true mentor myself, I try to do my best to help my younger collaborators in their research endeavours and career strategy. Fundamentally, the most important thing a mentor can do is to be himself a role model for the younger team members. Work had, play hard, accept your limitations, be humble in front of nature, which is always enigmatic, though much more intelligent than we are. Accept the defeat of your hypothesis as soon as possible, and generate a new one, until the next defeat. Be conscientious and happy as you confront yourself with the absurdity of the humane (and scientific) condition. Like Sisyphus in Albert Camus' chef d'oeuvre.

\section{What are the things you like most about running a lab and what are the things you like least?}

Well, I enjoy the interaction with my colleagues. For me, an ideal working day consists in walking around in the lab, meeting my collaborators by chance and chatting about their most recent experiments or thoughts. Such a day is better than any holiday that I can dream of. Of course, there is also the down side. I am not enthusiastic about the fact that I have to spend more than one third of my time searching for grant money and yet another third for administrative tasks including the organization of scientific journals, networks and conferences. I absolute hate to be obliged to solve internal conflicts (which fortunately are rare) or to motivate persons who work for obligation, not for fun (who fortunately are rare as well).

\section{If you could meet any scientist, currently living or from the past, who would it be and why?}

I am not sure whether I would prefer to meet Aristotle or Leonardo da Vinci. Both are fascinating in their prolific ambition. Without having more instruments than their bold eyes and their intuition, each of them invented an entire world. It would be funny to spend a sabbatical year with both of them. So my project is to take two years of sabbatical in a row, the first year with Aristotle and the second year with Leonardo, just for the sake of inspiration.

\section{If you could start over and choose a different career, what would it be?}

This phrase involves a speculative conditional tense and hence has no utility, neither in science nor in ordinary life. However, I will try my best to respond to the question. I might have been more successful, if I had been guided appropriately at the beginning of my career. For example, when I was 23 and a graduate student, I 
spent a few months in Wayne State University (Detroit) instead of choosing - let us say - Harvard or the MIT. At that time I did not even know that there were differences in the quality and prestige between Universities. Although I was totally determined to become a brilliant scientist when I was 20 or so, nobody told me how to achieve this goal. Nobody was available to give me any useful advice, probably because I was studying in a provincial University, deep in the Austrian Alps. So, my scientific infancy misstarted, and it took me a long time to find the right track.

Is teaching a substantial part of your current position? If so, what do you teach? Does it benefit your research, or benefit from your research?

I teach undergraduate courses on cell death mechanisms and immunogenic cell death. So, these courses benefit from my research. I also give some 30-40 lectures at international meetings per year. Moreover, I try to write one to two didactic papers for Nature Reviews per year, because this kind of article is widely used in post-graduate education.

Personal comments: Is there anything else you would be willing to share with us so we can know you as a person (e.g., hobbies, favourite book or movie, humorous anecdote relating to lab, outdoor activities you like to engage in, etc)? I think this is actually very important for the concluding paragraph as it adds a very human aspect to the article; we want to know a little about the PERSON behind Prof. Kroemer, not just his research.

Definitively, my favourite hobby is science. Beyond this, I enjoy reading in all five languages [ed. English, French, Italian, Spanish and German!] that I speak, and I have a broad (but frustrated) interest in literature, music and arts. I practice running (mostly in the streets in Paris), swimming (mostly in Corsica) and skiing (mostly in the Austrian and French Alps), as well once or twice per year - at least - five days of fasting in a row, obviously for the induction of autophagy. As you can see, I do believe that our laboratory results can be extrapolated to humans. Finally, but most importantly, I like to spend (too little?) time with my daughter Lea and my son Ulysses. I would like them to understand that they must follow a path of curiosity and existential doubt to find their own vocation, their driving force for a life enlightened by passion and love.

\section{Key Publications by G. Kroemer}

ZAMZAMI N, SUSIN SA, MARCHETTI P, HIRSCH T, GOMEZ-MONTERREY I, CASTEDO M, KROEMER G. (1996). Mitochondrial control of nuclear apoptosis. J Exp Med 183: 1533-1544.
SUSIN SA, ZAMZAMI N, CASTEDO M, HIRSCH T, MARCHETTI P, MACHO A, DAUGAS E, GEUSKENS M, KROEMER G (1996). Bcl-2 inhibits the mitochondrial release of an apoptogenic protease. J Exp Med 184: 1331-1341.

MARZO I, BRENNER C, ZAMZAMI N, SUSIN SA, BEUTNER G, BRDICZKA D, REMY R, XIE ZH, REED JC, KROEMER G (1998). The permeability transition pore complex: a target for apoptosis regulation by caspases and Bcl-2-related proteins. J Exp Med 187: 1261-1271.

RAVAGNAN L, GURBUXANI S, SUSIN SA, MAISSE C, DAUGAS E, ZAMZAMI N, MAKT,JAATTELAM, PENNINGER JM, GARRIDO C, KROEMER G (2001). Heatshock protein 70 antagonizes apoptosis-inducing factor. Nat Cell Biol3: 839-843.

OBEID M, TESNIERE A, GHIRINGHELLI F, FIMIA GM, APETOH L, PERFETTINI JL, CASTEDO M, MIGNOT G, METIVIER D, LAROCHETTE D, VAN EDERT P, CICCOSANTI F, PIACENTINI F, ZITVOGEL L, KROEMER G (2007). Calreticulin exposure dictates the immunogenicity of cancer cell death. Nat Med 13: 54-61.

TASDEMIR E, MAIURI MC, GALLUZZI L, VITALE I, DJAVAHERI-MERGNY M, D'AMELIO M, CRIOLLO A, MORSELLI E, ZHU C, HARPER F, NANNMARK U, SAMARA C, PINTON P, VICENCIO JM, CARNUCCIO R, MOLL UM, MADEO F, PATERLINI-BRECHOTP, RIZZUTOR, SZABADKAI G, PIERRON G, BLOMGREN K, TAVERNARAKISN, CODOGNO P, CECCONI F, KROEMERG (2008). Regulation of autophagy by cytoplasmic p53. Nat Cell Biol 10: 676-687.

MICHAUD M, MARTIN I, SUKKUWALAA, ADJEMIAN S, MAY, PELLEGATIP, SHEN S, KEPPO, SCOAZECM, MIGNOT G, RELLO-VARONAS, TAILLERM, MENGER L, VACCHELLI E, GALLUZZI L, GHIRINGHELLI F, GALLUZZI L, DI VIRGILIO F, ZITVOGEL L, KROEMER G (2011). Autophagy-dependent anticancer immune responses induced by chemotherapeutic agents in mice. Science 334: 1573-1577.

SENOVILLA L, VITALE I, MARTINS I, TAILLER M, PAILLERET C, MICHAUD M, GALLUZZI L, ADJEMIAN S, KEPP O, NISO-SANTANO M, SHEN S, MARIÑO G, CRIOLLO A, BOILĖVE A, JOB B, LADOIRE S, GHIRINGHELLI F, SISTIGU A, YAMAZAKI T, RELLO-VARONA S, LOCHER C, POIRIER-COLAME V, TALBOT M, VALENT A, BERARDINELLI F, ANTOCCIA A, CICCOSANTI F, FIMIA GM, PIACENTINI M, FUEYO A, MESSINA NL, LI M, CHAN CJ, SIGL V, POURCHER G, RUCKENSTUHL C, CARMONA-GUTIERREZ D, LAZAR V, PENNINGER JM, MADEO F, LÓPEZ-OTÍN C, SMYTHMJ, ZITVOGEL L, CASTEDO M, KROEMER $G$ (2012). An immunosurveillance mechanism controls cancer cell ploidy. Science 337: 1678-1684.

MAY, ADJEMIANS, MATTAROLLOSR, YAMAZAKIT, AYMERICL, YANG H, PORTELA CATANI JP, HANNANI D, DURET H, STEEGH K, MARTINS I, SCHLEMMER F, MICHAUDM, KEPPO, SUKKURWALAAQ, MENGERL, VACCHELLIE, DROIN N, GALLUZZI L, KRZYSIEK R, GORDON S, TAYLORPR, VAN ENDERTP, SOLARY E, SMYTH MJ, ZITVOGEL L, KROEMER G (2013). Anticancer chemotherapyinduced intratumoral recruitment and differentiation of antigen-presenting cells. Immunity 38: 729-741.

MARIÑO G, PIETROCOLAF, EISENBERG T, KONG Y, MALIKSA, ANDRYUSHKOVA A, SCHROEDER S, PENDL T, HARGER A, NISO-SANTANO M, ZAMZAMI N, SCOAZEC M, DURAND S, ENOT DP, FERNÁNDEZ ÁF, MARTINS I, KEPP O, SENOVILLA L, BAUVY C, MORSELLI E, VACCHELLI E, BENNETZEN M, MAGNES C, SINNER F, PIEBER T, LÓPEZ-OTÍN C, MAIURI MC, CODOGNO P, ANDERSEN JS, HILL JA, MADEO F, KROEMER G. (2014). Regulation of autophagy by cytosolic acetyl-coenzyme A. Mol Cell 53: 710-725. 


\section{Further Related Reading, published previously in the Int. J. Dev. Biol.}

Two decades of reproductive biomedicine and stem cell biology in Iran: the Royan Institute Sophie Rousseaux

Int. J. Dev. Biol. (2014) 58: 643-647

Two decades of reproductive biomedicine and stem cell biology in Iran: the Royan Institute Sophie Rousseaux

Int. J. Dev. Biol. (2014) 58: 643-647

Transgenic plants: from first successes to future applications

Mieke Van Lijsebettens, Geert Angenon and Marc De Block

Int. J. Dev. Biol. (2013) 57: 461-465

From the tumor-inducing principle to plant biotechnology and its importance for society Geert Angenon, Mieke Van Lijsebettensand Marc Van Montagu Int. J. Dev. Biol. (2013) 57: 453-460

Transgenic plants: from first successes to future applications Mieke Van Lijsebettens, Geert Angenon and Marc De Block Int. J. Dev. Biol. (2013) 57: 461-465

From the tumor-inducing principle to plant biotechnology and its importance for society Geert Angenon, Mieke Van Lijsebettensand Marc Van Montagu Int. J. Dev. Biol. (2013) 57: 453-460

Above the borderland between normal and neoplastic development Juan Aréchaga and Ivan Damjanov Int. J. Dev. Biol. (2012) 56: 939-948

Above the borderland between normal and neoplastic development Juan Aréchaga and Ivan Damjanov Int. J. Dev. Biol. (2012) 56: 939-948

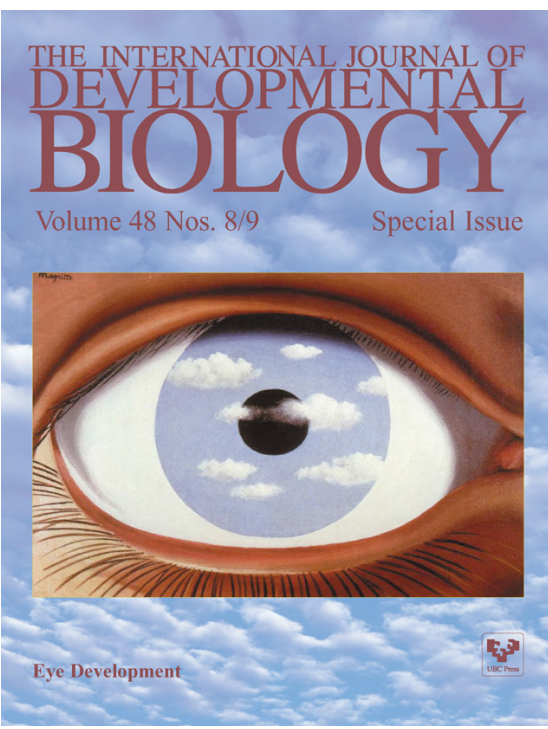

5 yr ISI Impact Factor $(2013)=2.879$
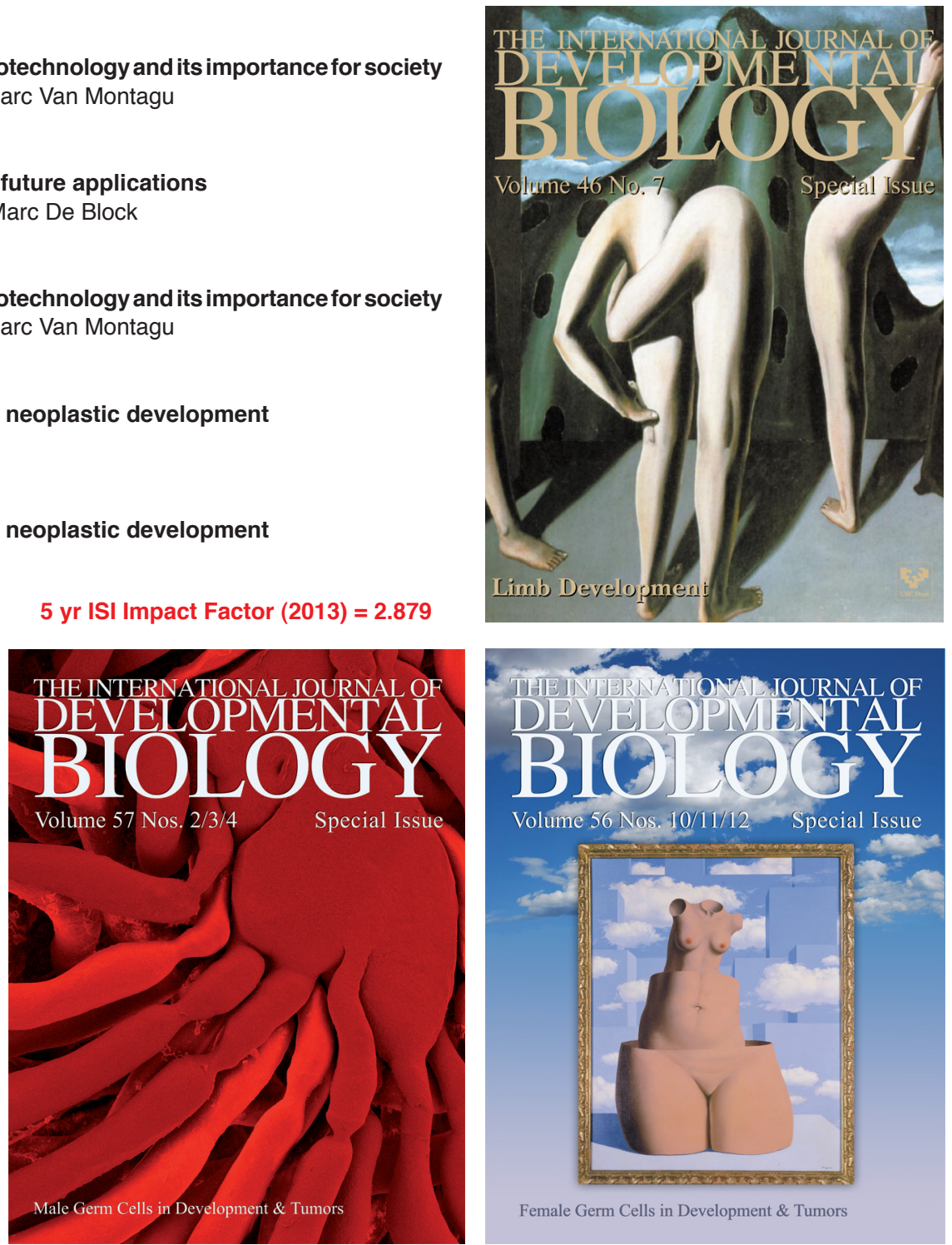

Volume 56 Nos. 10/11/12 - Special Issue

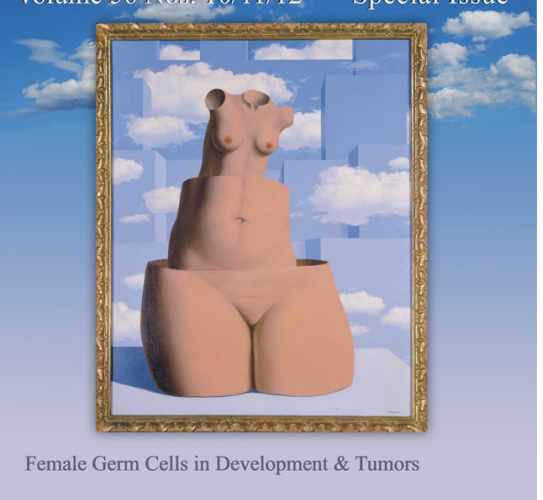

